\title{
PENGARUH PEMBELAJARAN BERBASIS MASALAH DAN INKUIRI DITINJAU DARI KEMANDIRIAN BELAJAR SISWA KELAS X SMA NEGERI KABUPATEN BLORA
}

\author{
Imam Mashuri
}

\begin{abstract}
Abstrak
Tujuan penelitian ini adalah untuk mengetahui: (1) Manakah model pembelajaran yang memberikan prestasi belajar matematika yang lebih baik, model pembelajaran berbasis masalah (PBM), inkuiri atau konvensional, (2) Manakah yang memberikan prestasi belajar matematika yang lebih baik, kemandirian belajar tinggi, kemandirian belajar sedang, atau kemandirian belajar rendah, (3) Pada masingmasing model pembelajaran, manakah yang memberikan prestasi belajar matematika yang lebih baik, kemandirian belajar tinggi, kemandirian belajar sedang, atau kemandirian belajar rendah. (4) Pada masingmasing klasifikasi kemandirian belajar siswa, manakah model pembelajaran yang memberikan prestasi belajar matematika yang lebih baik, model PBM, inkuiri atau konvensional.

Penelitian ini merupakan penelitian eksperimental semu. Populasi dalam penelitian ini adalah seluruh siswa kelas X SMA Negeri Kabupaten Blora Provinsi Jawa Tengah tahun pelajaran 2011/2012. Teknik pengambilan sampel dilakukan dengan stratified cluster random sampling. Sampel dalam penelitian ini berjumlah 287 siswa, dengan rincian 92 siswa pada kelas eksperimen satu, 96 siswa pada kelas eksperimen dua, dan 99 siswa pada kelas kontrol. Instrumen yang digunakan untuk mengumpulkan data adalah tes kemampuan awal, angket kemandirian, dan tes prestasi belajar. Uji coba instrumen tes meliputi validitas isi, tingkat kesukaran, daya pembeda, dan reliabilitas. Uji coba instrumen angket meliputi validitas isi, konsistensi internal, dan reliabilitas. Uji prasyarat meliputi uji normalitas menggunakan metode Lilliefors dan uji homogenitas variansi menggunakan metode Bartlett. Dengan $\alpha=$ 0,05 , diperoleh kesimpulan bahwa sampel berasal dari populasi yang berdistribusi normal dan mempunyai variansi yang homogen. Uji keseimbangan terhadap data kemampuan awal menggunakan analisis variansi satu jalan dengan sel tak sama diperoleh kesimpulan bahwa ketiga kelas mempunyai kemampuan awal yang seimbang. Pengujian hipotesis menggunakan analisis variansi dua jalan dengan sel tak sama.

Berdasarkan hasil pengujian hipotesis diperoleh kesimpulan bahwa (1) Model pembelajaran inkuiri menghasilkan prestasi belajar matematika lebih baik dibandingkan model PBM, model PBM menghasilkan prestasi belajar matematika lebih baik dibandingkan model pembelajaran konvensional, dan model pembelajaran Inkuiri menghasilkan prestasi belajar matematika lebih baik dibandingkan model pembelajaran konvensional, (2) Siswa dengan kemandirian belajar tinggi memiliki prestasi belajar matematika lebih baik dibandingkan siswa berkemandirian belajar sedang, siswa dengan kemandirian belajar sedang memiliki prestasi yang sama baiknya dengan siswa berkemandirian belajar rendah, dan siswa dengan kemandirian belajar tinggi memiliki prestasi yang lebih baik dibandingkan siswa dengan kemandirian belajar rendah, (3) Pada model pembelajaran inkuiri, siswa dengan kemandirian belajar tinggi memiliki prestasi belajar matematika sama baiknya dengan siswa berkemandirian belajar sedang, siswa dengan kemandirian belajar tinggi memiliki prestasi yang lebih baik dibandingkan siswa berkemandirian belajar rendah, dan siswa dengan kemandirian belajar sedang memiliki prestasi yang sama baiknya dengan siswa dengan kemandirian belajar rendah. Pada model PBM dan konvensional, ketiga klasifikasi kemandirian belajar siswa memberikan prestasi belajar yang sama baiknya, (4) Pada siswa dengan kemandirian belajar tinggi, model pembelajaran inkuiri menghasilkan prestasi belajar matematika lebih baik dibandingkan model PBM, model PBM menghasilkan prestasi belajar matematika sama baiknya dengan model pembelajaran konvensional, dan model pembelajaran inkuiri menghasilkan prestasi belajar matematika lebih baik dibandingkan model pembelajaran konvensional. Pada siswa dengan kemandirian belajar sedang dan rendah, ketiga model pembelajaran menghasilkan prestasi belajar matematika yang sama baiknya.
\end{abstract}




\section{Kata kunci: Inkuiri, Pembelajaran Berbasis Masalah (PBM), Konvensional, Kemandirian Belajar Siswa}

\section{PENDAHULUAN}

Pembangunan di bidang pendidikan merupakan masalah yang menonjol pada saat ini terkait dengan alokasi $20 \%$ anggaran negara bagi pendidikan dalam rangka peningkatan dari segi kualitas maupun kuantitas. Pendidikan memegang peranan penting dalam menciptakan masyarakat yang cerdas, damai, terbuka, dan demokratis. Pendidikan menjadi salah satu modal penting untuk memajukan sebuah bangsa karena kesejahteraan dan kemajuan sebuah bangsa dapat dilihat dari tingkat pendidikannya. Peningkatan mutu pendidikan diharapkan dapat mengangkat harkat dan martabat bangsa Indonesia. Hal ini tercantum dalam Undang-Undang Republik Indonesia Nomor 20 tahun 2003 tentang Sistem Pendidikan Nasional pasal 1 ayat 1 yang menjelaskan:

Pendidikan adalah usaha sadar dan terencana untuk mewujudkan suasana belajar dan proses pembelajaran agar peserta didik secara aktif mengembangkan potensi dirinya untuk memiliki kekuatan spiritual keagamaan, pengendalian diri, kepribadian, kecerdasan, akhlak mulia, serta keterampilan yang diperlukan dirinya, masyarakat, bangsa, dan negara.

Keberhasilan suatu pendidikan tidak terlepas dari keberhasilan dalam proses pembelajaran. Pembelajaran merupakan proses komunikasi dua arah yang dibangun untuk mengembangkan kreativitas berpikir peserta didik sehingga dapat meningkatkan kemampuan mengkontruksikan pengetahuan baru sebagai upaya peningkatan penguasaan yang baik terhadap materi pelajaran.

Keberhasilan suatu proses pembelajaran dipengaruhi oleh berbagai komponen yang ada di dalamnya, antara lain: tujuan, bahan atau materi, metode atau model pembelajaran, media, guru dan siswa. Terkait dengan model pembelajaran, berdasarkan observasi peneliti pada beberapa sekolah di Kabupaten Blora, ditemukan bahwa hingga saat ini masih banyak pembelajaran yang digunakan guru dalam pembelajaran matematika di sekolah dengan menggunakan pembelajaran konvensional, yang cenderung berjalan searah, berpusat pada guru dan kurang melibatkan siswa dalam belajar mengajar sehingga menyebabkan siswa kesulitan dalam memahami konsep atau materi yang diberikan. Cara pembelajaran konvensional seperti ini tidak merangsang siswa untuk mengerti tentang apa yang dipelajari, dan pada gilirannya nanti siswa tidak memiliki kemampuan untuk memecahkan masalah yang terkait dengan materi pelajaran yang siswa pelajari.

Untuk mengatasi masalah-masalah tersebut, maka diperlukan suatu pembelajaran yang sesuai, selain pembelajaran tradisional 
(konvensional). Dalam proses pembelajaran ini tidak lagi siswa menjadi seorang pendengar, tetapi siswa dapat memecahkan masalah dengan sendirinya sesuai dengan kecakapan yang siswa miliki untuk berpikir kritis dalam menghadapi masalah serta siswa menerima ataupun menemukan dan menggali sendiri pemecahan masalah pada pelajaran Matematika. Pembelajaran yang sesuai dengan yang dimaksud adalah Problem Based Learning (PBL) atau yang sering dikenal dengan Pembelajaran Berbasis Masalah (PBM).

Untuk mencapai hasil belajar yang maksimal pada akhir proses belajar mengajar, siswa perlu untuk diberi tugas baik itu berupa quis ataupun tugas rumah. Tugas berfungsi sebagai balikan dan penguatan serta merupakan kondisi yang diperlukkan untuk mengembangkan ketrampilan komplek, tugas tersebut dapat mengembangkan kemandirian siswa.

\section{Tujuan Penelitian}

Tujuan penelitian yang akan dicapai dalam penelitian ini adalah:

1. Untuk mengetahui manakah yang memberikan prestasi belajar matematika yang lebih baik, model pembelajaran berbasis masalah, model pembelajaran inkuiri atau model pembelajaran konvensional.

2. Untuk mengetahui manakah yang memberikan prestasi belajar matematika siswa dengan kemandirian belajar tinggi, kemandirian belajar sedang, atau kemandirian belajar rendah.

3. Untuk mengetahui pada masing-masing model pembelajaran, manakah yang memberikan prestasi belajar matematika yang lebih baik, siswa dengan kemandirian belajar tinggi, kemandirian belajar sedang, atau kemandirian belajar rendah.

4. Untuk mengetahui pada masing-masing klasifikasi kemandirian belajar siswa, manakah yang memberikan prestasi belajar matematika yang lebih baik, model pembelajaran berbasis masalah, pembelajaran inkuiri atau model pembelajaran konvensional.

\section{LANDASAN TEORI}

Problem Based Learning (PBL)/ Pembelajaran Berbasis Masalah (PBM)

Menurut Wina Sanjaya (2010:217), tahaptahap pembelajaran berbasis masalah adalah sebagai berikut:

1) Merumuskan masalah, yaitu langkah siswa menentukan masalah yang akan dipecahkan.

2) Menganalisis masalah, yaitu langkah siswa meninjau masalah secara kritis dari berbagai sudut pandang.

3) Merumuskan hipotesis, yaitu langkah siswa merumuskan berbagai kemungkinan pemecahan sesuai dengan pengetahuan yang dimilikinya.

4) Mengumpulkan data, yaitu langkah siswa mencari dan menggambarkan informasi yang diperlukan untuk pemecahan masalah. 
5) Penggunaan hipotesis, yaitu langkah siswa mengambil atau merumuskan kesimpulan sesuai dengan penerimaan dan penolakan hipotesis yang diajukan.

6) Merumuskan rekomendasi pemecahan masalah, yaitu langkah siswa menggambarkan rekomendasi yang dapat dilakukan sesuai rumusan hasil pengujian hipotesis dan rumusan kesimpulan.

Dalam penelitian ini pembelajaran yang akan dilakukan adalah sebagaimana Tabel 1 .

\section{Tabel 1 Sintaksis untuk PBM}

\begin{tabular}{|c|l|}
\hline \hline \multicolumn{1}{|c|}{ Fase } & \multicolumn{1}{c|}{ Peran Guru } \\
\hline $\begin{array}{c}\text { Fase 1: Memberikan } \\
\text { orientasi/penjelasan } \\
\text { yang akan dipelajari. }\end{array}$ & $\begin{array}{l}\text { Guru mempresentasikan materi pelajaran } \\
\text { dengan memanfaatkan alat peraga atau } \\
\text { media masih dimungkinkan. }\end{array}$ \\
\hline $\begin{array}{c}\text { Fase 2: Mengorganisasikan siswa } \\
\text { untuk memahami masalah } \\
\text { dan pemecahannya. }\end{array}$ & $\begin{array}{l}\text { Guru memberi contoh soal, dan } \\
\text { memecahkannya bersama-sama dengan } \\
\text { siswa. }\end{array}$ \\
\hline $\begin{array}{c}\text { Fase 3: Memberikan masalah. } \\
\text { Femecahan masalah. }\end{array}$ & $\begin{array}{l}\text { Guru memberikan 1 atau 2 soal yang harus } \\
\text { dipecahkan siswa berdasarkan persyaratan } \\
\text { soal sebagai sebuah pemecahan masalah. }\end{array}$ \\
\hline $\begin{array}{c}\text { Fase 5: } \\
\text { Menganalisis dan } \\
\text { mengevaluasi proses }\end{array}$ & $\begin{array}{l}\text { Guru membimbing siswa untuk } \\
\text { menyelesaikan soal pemecahan masalah. } \\
\text { refleksi terhadap hasil pemecahannya dan } \\
\text { proses-proses pemecahan yang mereka } \\
\text { lakukan. }\end{array}$ \\
\hline
\end{tabular}

\section{Pembelajaran Inkuiri (inquiry)}

Menurut Gulo (2002:93-99), inkuiri tidak hanya mengembangkan kemampuan intelektual tetapi seluruh potensi yang ada termasuk pengembangan emosional dan pengembangan keterampilan. Pada hakikatnya, inkuiri ini merupakan proses. Proses ini bermula dari merumuskan masalah, mengembangkan hipotesis, mengumpulkan bukti, menguji hipotesis dan menarik kesimpulan sementara, menguji kesimpulan sementara supaya sampai pada kesimpulan yang pada taraf tertentu diyakini oleh peserta didik yang bersangkutan.

Dari beberapa pendapat tentang langkah-langkah pembelajaran inkuiri maka langkah-langkah pembelajaran inkuiri dalam penelitian ini adalah sebagamana Tabel 2. 
Tabel 2 Sintaksis untuk pembelajaran inkuiri

\begin{tabular}{|c|l|}
\hline Tahap & Peran Guru \\
\hline $\begin{array}{c}\text { Tahap 1: Observasi untuk menemukan } \\
\text { masalah }\end{array}$ & $\begin{array}{l}\text { Guru menyajikan kejadian-kejadian atau } \\
\text { fenomena yang memungkinkan siswa } \\
\text { menemukan masalah }\end{array}$ \\
\hline Tahap 2: Merumuskan masalah & $\begin{array}{l}\text { Guru membimbing siswa merumuskan } \\
\text { masalah penelitian berdasarkan kejadian dan } \\
\text { fenomena yang disajikannya }\end{array}$ \\
\hline $\begin{array}{c}\text { Tahap 3: Mengajukan hipotesis } \\
\text { lain) }\end{array}$ & $\begin{array}{l}\text { Guru membimbing siswa untuk mengajukan } \\
\text { hipotesis terhadap masalah yang telah } \\
\text { dirumuskannya }\end{array}$ \\
\hline $\begin{array}{c}\text { Tahap 4: Melaksanakan eksperimen } \\
\text { Tahap 5: Analisis data }\end{array}$ & $\begin{array}{l}\text { Selama siswa bekerja, Guru membimbing } \\
\text { dan memfasilitasi }\end{array}$ \\
\hline $\begin{array}{c}\text { Tahap 6: Penarikan kesimpulan dan } \\
\text { penemuan }\end{array}$ & $\begin{array}{l}\text { Guru membantu siswa menganalisis data } \\
\text { (mengolah data dan informasi yang telah } \\
\text { diperoleh para siswa) supaya menemukan } \\
\text { suatu konsep }\end{array}$ \\
\hline $\begin{array}{l}\text { kesimpulan berdasarkan data dan } \\
\text { menemukan sendiri konsep yang ingin } \\
\text { ditanamkan. }\end{array}$ \\
\hline
\end{tabular}

\section{Pembelajaran Konvensional}

Menurut Goos (2004:259):

"in Mathematics classroom using a tradisional, textbook-dominated approach, effective participation involves students in listening to and wacthing the teacher demonstrate mathematical procedures, and then practicing what was demonstrated by completing textbook exercise".

Dari pendapat ini, proses belajar tradisional adalah proses belajar mengandalkan buku, siswa hanya melihat dan mendengar guru mengajar prosedur matematika dan akhirnya siswa mengerjakan latihan. Pelaksanaan pembelajaran konvensional biasanya secara klasikal yaitu guru menyampaikan materi pelajaran kepada sejumlah siswa secara serempak pada waktu dan tempat yang sama. Karena pada model pembelajaran guru lebih dominan, maka siswa cenderung pasif, kurang memperoleh kesempatan untuk mengembangkan kreativitasnya. Dengan demikian pembela- 
jaran konvensional dipandang tidak sesuai dengan pembelajaran yang berdasarkan konstruktivisme.
Dalam penelitian ini langkah-langkah pembelajaran konvensional yang akan dilakukan adalah sebagaimaa Tabel 3.

Tabel 3. Sintaksis untuk pembelajaran konvensional

\begin{tabular}{|l|l|}
\hline \multicolumn{1}{|c|}{ Fase } & \multicolumn{1}{c|}{ Aktivitas Guru } \\
\hline $\begin{array}{l}\text { Fase 1: Menyampaikan tujuan dan } \\
\text { mempersiapkan siswa }\end{array}$ & $\begin{array}{l}\text { Guru menjelaskan tujuan pembelajaran, } \\
\text { pentingnya pembelajaran, mempersiapkan } \\
\text { siswa untuk belajar }\end{array}$ \\
\hline $\begin{array}{l}\text { Fase 2: Mendemonstrasikan } \\
\text { keterampilan (pengetahuan prosedural) } \\
\text { atau mempresentasikan pengetahuan } \\
\text { (deklaratif) }\end{array}$ & $\begin{array}{l}\text { Guru mendemonstrasikan keterampilan } \\
\text { dengan benar atau menyajikan informasi } \\
\text { tahap demi tahap }\end{array}$ \\
\hline Fase 3: Membimbing pelatihan & $\begin{array}{l}\text { Guru merencanakan dan memberi bimbingan } \\
\text { pelatihan }\end{array}$ \\
\hline $\begin{array}{l}\text { Fase 4: Mengecek pemahaman dan } \\
\text { memberikan umpan balik }\end{array}$ & $\begin{array}{l}\text { Guru mengecek apakah siswa telah berhasil } \\
\text { melakukan tugas dengan baik, memberi } \\
\text { umpan balik }\end{array}$ \\
\hline $\begin{array}{l}\text { Fase 5: Memberikan kesempatan untuk } \\
\text { pelatihan lanjutan }\end{array}$ & $\begin{array}{l}\text { Guru mempersiapkan kesempatan untuk } \\
\text { melakukan pelatihan lanjutan }\end{array}$ \\
\hline
\end{tabular}

\section{Kemandirian Belajar Siswa}

Kemandirian belajar atau Self-Regulated Learning diperlukan agar siswa mempunyai tanggung jawab dalam mengatur dan mendisiplinkan dirinya, selain itu dalam mengembangkan kemampuan belajar atas kemauan sendiri. Kemandirian dalam belajar dapat diartikan sebagai kegiatan belajar aktif, yang didorong oleh niat atau motif untuk menguasai sesuatu kompetensi guna mengatasi sesuatu masalah, dan dibangun dengan bekal pengetahuan atau kompetensi yang telah dimiliki (Haris Mudjiman, 2002:7). Sikap tersebut perlu dimiliki oleh siswa sebagai peserta didik karena hal tersebut merupakan ciri dari kedewasaan orang terpelajar. Manfaat dari kemandirian siswa belum banyak dirasakan oleh para siswa. Akan tetapi, sebagian dari mereka yang berhasil karena kemandirian dalam belajar tidak terfokus pada kehadiran guru atau tatap muka di kelas, melainkan pada pemanfaatan perpustakaan atau membentuk kelompok belajar. Kemandirian belajar siswa memiliki manfaat terhadap kemampuan kognisi, afeksi, dan psikomotorik siswa, manfaat tersebut seperti di bawah ini: 
a. Memupuk tanggung jawab

b. Meningkatkan keterampilan

c. Memecahkan masalah

d. Mengambil keputusan

e. Berpikir kreatif

f. Berpikir kritis

g. Percaya diri yang kuat

h. Menjadi guru bagi dirinya sendiri

(Martinis Yamin \& Bansu I. Ansari, 2008:19)

Menurut pengertian tersebut diatas, peneliti menyimpulkan bahwa kemandirian belajar siswa merupakan cermin sikap kreatif, kebebasan dalam bertindak dan tanggung jawab yang ditandai dengan adanya inisiatif belajar dan keinginan mendapat pengalaman baru. Kemandirian siswa mempunyai manfaat yang besar bagi siswa baik bagi pembentukan pribadi siswa maupun dalam peningkatan prestasi belajar siswa. Indikator bahwa individu sudah menerapkan kemandirian belajar adalah individu tersebut mengalami perubahan dalam kebiasaan belajar, yaitu dapat memahami masalah, dapat menyusun perencanaan, melaksanakan rencana, melihat kembali atau memeriksa kesesuaian dengan yang dipertanyakan, dan mampu belajar secara mandiri/individual.

\section{METODOLOGI PENELITIAN}

Penelitian ini merupakan penelitian eksperimental semu (quasi-experimental research) yaitu peneliti tidak memungkinkan untuk mengontrol semua variabel yang relevan. Menurut Budiyono (2003:82-83), tujuan penelitian eksperimental semu adalah untuk memperoleh informasi yang merupakan perkiraan bagi informasi yang dapat diperoleh dengan eksperimen yang sebenarnya dalam keadaan yang tidak memungkinkan untuk mengontrol dan/atau memanipulasikan semua variabel yang relevan.

Sebelum memulai perlakuan, terlebih dahulu mengecek keadaan kemampuan awal dari sampel yang akan dikenai perlakuan. Tujuannya untuk mengetahui apakah sampel tersebut dalam keadaan seimbang. Data yang digunakan untuk menguji keseimbangan adalah data kemampuan awal. Ketiga kelompok sampel tersebut diasumsikan sama dalam semua segi yang relevan dan hanya berbeda dalam penggunaan model pembelajaran. Rancangan penelitian yang digunakan dalam penelitian ini adalah rancangan faktorial $3 \times 3$. Populasi penelitian ini adalah siswa kelas X SMA Negeri di Kabupaten Blora tahun pelajaran 2011/2012. Teknik pengambilan sampel dilakukan dengan cara Stratified Cluster Random Sampling, yaitu dengan cara pengelompokkan sekolah berdasarkan peringkat nilai Ujian Nasional tahun pelajaran 2009/2010 Kabupaten Blora menjadi tiga kelompok yaitu kelompok atas, kelompok tengah, dan kelompok bawah. Dengan cara diundi sehingga terambil masing-masing kelompok atas, tengah dan bawah sebagai berikut:

(1). SMA Negeri 1 Cepu dari kelompok atas,

(2). SMA Negeri 1 Randublatung dari kelompok tengah dan

(3). SMA Negeri 2 Cepu kelompok bawah.

Dengan cara diundi pula, untuk memilih sampel masing-masing kelompok: 1). SMA 
Negeri 1 Cepu dari 7 kelas, setelah diundi yang terambil adalah kelas $\mathrm{XD}, \mathrm{XF}$ dan $\mathrm{XG}, 2)$. SMA Negeri 1 Randublatung dari 7 kelas, setelah diundi yang terambil adalah kelas $\mathrm{XB}$, XF dan XG dan 3). SMA Negeri 2 Cepu terdiri dari 6 kelas, setelah diundi yang terambil adalah kelas XA, XB dan XD.

\section{Teknik Pengumpulan Data}

\section{Metode Dokumentasi}

Menurut Budiyono (2003:54), metode dokumentasi adalah cara pengumpulan data dengan melihatnya dalam dokumen-dokumen yang telah ada. Metode dokumentasi yang digunakan dalam penelitian ini adalah pengambilan nilai UN matematika SMA tahun pelajaran 2009/2010 yang selanjutnya digunakan untuk menentukan kriteria sekolah yang akan digunakan untuk penelitian.

\section{Metode Angket}

Menurut Budiyono (2003:47), metode angket adalah cara pengumpulan data melalui pengajuan pertanyaan-pertanyaan tertulis kepada subyek penelitian, responden, atau sumber data dan jawabannya diberikan pula secara tertulis. Dalam penelitian ini angket yang digunakan adalah angket tentang kemandirian belajar siswa, berupa angket pilihan ganda sebanyak 40 item, dengan alternatif 5 jawaban. Pemberian skor menggunakan skala Likert untuk item positif jika menjawab A diberi skor 5, B diberi skor 4, C diberi skor 3, D diberi skor 2 dan E diberi skor 1. Adapun untuk item negatif jika menjawab A diberi skor 1, B diberi skor 2, C diberi skor 3, D diberi skor 4, dan E diberi skor 5.

\section{Metode Tes}

Metode tes adalah cara pengumpulan data yang menghadapkan sejumlah pertanyaan atau suruhan-suruhan kepada subjek penelitian (Budiyono, 2003:54). Metode tes dalam penelitian ini digunakan untuk mengumpulkan data mengenai prestasi belajar matematika siswa. Data tentang prestasi belajar matematika siswa diperoleh dari instrumen tes yang dibuat oleh peneliti. Instrumen yang digunakan untuk mengumpulkan data prestasi belajar matematika siswa diujicobakan terlebih dahulu untuk mengetahui daya beda, tingkat kesukaran dan reliabilitas. Dalam penelitian ini, bentuk tes yang digunakan adalah soal pilihan ganda. Pemberian skor item tes adalah skor 1 untuk jawaban benar dan skor 0 untuk jawaban salah.

\section{HASIL DAN PEMBAHASAN}

Untuk menguji hipotesis penelitian ini menggunakan perhitungan analisis variansi dua jalan sel tak sama dengan tingkat signifikansi 0,05. Kemudian dilanjutkan uji pasca lanjut anava dengan metode Scheffe'. Data yang diambil dari 287 siswa yang berasal dari tiga sekolah dengan kriteria sekolah yang berbeda yaitu sekolah kategori tinggi, sedang dan rendah. Perhitungan secara lengkap pada Lampiran 26. Rangkuman dari hasil perhitungan analisis variansi dua jalan sel tak sama disajikan pada Tabel 4. 
Tabel 4. Rangkuman Analisis Variansi Dua Jalan dengan Sel Tak Sama

\begin{tabular}{|l|r|c|r|r|r|l|}
\hline \hline & \multicolumn{6}{|c|}{ Analisis Variansi Dua Jalan Sel Tak Sama } \\
\hline \hline & $J K$ & $d K$ & $R K$ & $F_{o b s}$ & $F_{\alpha}$ & Keputusan \\
\hline Metode $(A)$ & 6586,3131 & 2 & 3293,1566 & 12,8080 & 3,0282 & $H_{0 A}$ Ditolak \\
\hline Kemandirian Belajar $(B)$ & 3268,6576 & 2 & 1634,3288 & 6,3564 & 3,0282 & $H_{0 B}$ Ditolak \\
\hline Interaksi $(A B)$ & 4112,3790 & 4 & 1634,0948 & 3,9986 & 2,4041 & $H_{0 A B}$ Ditolak \\
\hline Galat & 21947,0265 & 278 & 257,1168 & & & \\
\hline \hline Total & 7374,0232 & 286 & 12,8080 & & & \\
\hline \hline
\end{tabular}

Dari tabel tersebut, dapat ditarik kesimpulan sebagai berikut:

a. $H_{0 A}$ ditolak sehingga paling sedikit ada satu $\alpha_{i} \neq 0$

Hal ini berarti terdapat perbedaan prestasi belajar matematika antara siswa yang mendapat pembelajaran inkuiri, dengan siswa yang mendapat pembelajaran PBM, dan siswa yang mendapat pembelajaran dengan konvensional.

b. $H_{0 B}$ ditolak sehingga paling sedikit ada satu $\beta_{j} \neq 0$

Hal ini berarti terdapat perbedaan prestasi belajar matematika antara siswa yang mempunyai kemandirian belajar siswa tinggi, sedang, dan rendah. c. $H_{0 A B}$ ditolak sehingga paling sedikit ada satu $(\alpha \beta)_{i j} \neq 0$

Hal ini berarti terdapat interaksi antara model pembelajaran dan kemandirian belajar siswa terhadap prestasi belajar matematika.

\section{Uji Lanjut Pasca Anava}

Dari rangkuman analisis variansi dua jalan dengan sel tak sama di atas telah diperoleh bahwa:

a. $H_{0 A}$ ditolak, maka perlu dilakukan uji komparasi ganda antar baris.

Uji lanjut analisis variansi dua jalan dengan sel tak sama dengan menggunakan metode Scheffe. Hasil perhitungan komparasi ganda antar baris dapat dilihat pada Tabel 6 .

Tabel 5 Rerata Marginal untuk data prestasi belajar siswa

\begin{tabular}{|l|c|c|c|c|}
\hline \multirow{2}{*}{ Model Pembelajaran } & \multicolumn{3}{|c|}{ Kemandirian belajar siswa } & \multirow{2}{*}{$\begin{array}{c}\text { Rataan } \\
\text { Marginal }\end{array}$} \\
\cline { 2 - 4 } & Tinggi & Sedang & Rendah & Ma, \\
\hline Inkuiri & 69,2501 & 57,8889 & 47,5758 & 60,3624 \\
\hline PBM & 50,0000 & 53,6872 & 50,1389 & 51,8399 \\
\hline Konvensional & 47,1767 & 47,3759 & 43,4375 & 46,0606 \\
\hline Rataan Marginal & 58,3922 & 52,3116 & 46,6667 & \\
\hline
\end{tabular}


Tabel 6 Rangkuman Komparasi Antar Baris

\begin{tabular}{|c|c|c|c|c|c|cr|}
\hline $\boldsymbol{H}_{\mathbf{0}}$ & $\left(\boldsymbol{X}_{\boldsymbol{i}}-\boldsymbol{X}_{\boldsymbol{j}}\right)^{\mathbf{2}}$ & $\frac{\mathbf{1}}{n_{\boldsymbol{i}}}+\frac{\mathbf{1}}{\boldsymbol{n}_{\boldsymbol{j}}}$ & $R K G$ & Fobs & Fkritis & \multicolumn{2}{|c|}{ Keputusan } \\
\hline$\mu_{1 .}=\mu_{2 .}$ & 72,6317 & 0,0213 & 257,1168 & 13,2708 & 6,0565 & $H_{0}$ & Ditolak \\
\hline$\mu_{2 .}=\mu_{3 .}$ & 33,4006 & 0,0205 & 257,1168 & 6,3313 & 6,0565 & $H_{0}$ & Ditolak \\
\hline$\mu_{1 .}=\mu_{3 .}$ & 204,5400 & 0,0210 & 257,1168 & 37,9348 & 6,0565 & $H_{0}$ & Ditolak \\
\hline
\end{tabular}

Berdasarkan tabel di atas dapat

disimpulkan sebagai berikut :

1). Ada perbedaan prestasi belajar antara siswa dengan pembelajaran inkuiri dan PBM. Apabila dilihat dari rerata pembelajaran inkuiri adalah 60,3624 dan PBM adalah 51,8399, siswa dengan pembelajaran inkuiri mempunyai prestasi yang lebih baik daripada siswa dengan pembelajaran PBM.

2). Ada perbedaan prestasi belajar antara siswa dengan pembelajaran PBM dan konvensional. Apabila dilihat dari rerata PBM adalah 51,8399 dan pembelajaran konvensional adalah 46,0606, sehingga siswa dengan PBM mempunyai prestasi yang lebih baik daripada siswa dengan pembelajaran konvensional.

3). Ada perbedaan prestasi belajar antara siswa dengan pembelajaran inkuiri dan konvensional. Apabila dilihat dari rerata pembelajaran inkuiri adalah 60,3624 dan pembelajaran konvensional adalah 46,0606, sehingga siswa dengan pembelajaran inkuiri mempunyai prestasi yang lebih baik daripada siswa dengan pembelajaran konvensional.

b. $H_{0 B}$ ditolak, maka perlu dilakukan uji komparasi ganda antar kolom.

Rangkuman uji komparasi ganda dengan metode Scheffe' disajikan dalam tabel 7.

Berdasarkan tabel 7 dapat disimpulkan sebagai berikut:

1) $F_{o b s} \in D K$ sehingga $H_{0}$ ditolak artinya ada perbedaan prestasi belajar antara siswa dengan kemandirian belajar tinggi dan sedang. Apabila dilihat dari rerata kemandirian belajar siswa yang tinggi adalah 58,3922 dan rerata siswa dengan kemandirian belajar siswa yang sedang adalah 52,3166, sehingga siswa dengan kemandirian belajar siswa tinggi mempunyai prestasi yang lebih baik daripada siswa dengan kemandirian belajar siswa yang sedang.

2) $\quad F_{o b s} \notin D K$ sehingga $H_{0}$ diterima artinya tidak ada perbedaan prestasi belajar antara siswa dengan kemandirian belajar sedang dan rendah.

3) $F_{o b s} \in D K$ sehingga $H_{0}$ ditolak artinya ada perbedaan prestasi belajar antara siswa 
dengan kemandirian belajar tinggi dan rendah. Apabila dilihat dari rerata kemandirian belajar siswa tinggi adalah 58,3922 dan rerata siswa dengan kemandirian belajar siswa yang rendah adalah 46,6667, sehingga siswa dengan kemandirian belajar tinggi mempunyai prestasi yang lebih baik daripada siswa dengan kemandirian belajar rendah.

Tabel 7 Hasil Uji Komparasi Ganda untuk Kemandirian belajar siswa

\begin{tabular}{|l|c|c|c|c|c|cc|}
\hline$H_{0}$ & $\left(X_{i}-X_{j}\right)^{2}$ & $\frac{1}{n_{i}}+\frac{1}{n_{j}}$ & $R K G$ & $F_{\text {obs }}$ & $F_{\text {tabel }}$ & \multirow{2}{*}{ Keputusan } \\
\hline$\mu_{.1}=\mu_{.2}$ & 36,9741 & 0,0213 & 257,1168 & 6,7557 & 6,0565 & $H_{0}$ & Ditolak \\
\hline$\mu_{.2}=\mu_{.3}$ & 31,8648 & 0,0205 & 257,1168 & 6,0402 & 6,0565 & $H_{0}$ & Diterima \\
\hline$\mu_{.1}=\mu_{.3}$ & 137,4880 & 0,0210 & 257,1168 & 25,4991 & 6,0565 & $H_{0}$ & Ditolak \\
\hline
\end{tabular}

c. $H_{0 A B}$ ditolak, maka perlu dilakukan uji komparasi ganda antar sel.

Rangkuman uji komparasi ganda dengan metode Scheffe' disajikan dalam tabel berikut. Perhitungan selengkapnya dapat dilihat pada Lampiran 22.

Tabel 8 Hasil uji komparasi ganda antar sel pada baris yang sama

\begin{tabular}{|c|c|c|cc|}
\hline$H_{0}$ & $F_{\text {obs }}$ & $F_{\text {tabel }}$ & \multicolumn{2}{|c|}{ Keputusan } \\
\hline$\mu_{11}=\mu_{12}$ & 8,6060 & 15,7743 & $H_{0}$ & $\mu_{11}=\mu_{12}$ \\
\hline$\mu_{11}=\mu_{13}$ & 25,9329 & 15,7743 & $H_{0}$ & $\mu_{11}=\mu_{13}$ \\
\hline$\mu_{12}=\mu_{13}$ & 5,2504 & 15,7743 & $H_{0}$ & $\mu_{12}=\mu_{13}$ \\
\hline$\mu_{21}=\mu_{22}$ & 0,8629 & 15,7743 & $H_{0}$ & $\mu_{21}=\mu_{22}$ \\
\hline$\mu_{21}=\mu_{23}$ & 0,0009 & 15,7743 & $H_{0}$ & $\mu_{21}=\mu_{23}$ \\
\hline$\mu_{22}=\mu_{23}$ & 0,7780 & 15,7743 & $H_{0}$ & $\mu_{22}=\mu_{23}$ \\
\hline$\mu_{31}=\mu_{32}$ & 0,0024 & 15,7743 & $H_{0}$ & $\mu_{31}=\mu_{32}$ \\
\hline$\mu_{31}=\mu_{33}$ & 0,6657 & 15,7743 & $H_{0}$ & $\mu_{31}=\mu_{33}$ \\
\hline$\mu_{32}=\mu_{33}$ & 1,1485 & 15,7743 & $H_{0}$ & $\mu_{32}=\mu_{33}$ \\
\hline
\end{tabular}

Berdasarkan tabel di atas dapat disimpulkan sebagai berikut:

1) $F_{\text {obs }} \notin D K$ sehingga $H_{0}$ diterima artinya tidak ada perbedaan prestasi belajar antara siswa dengan kemandirian belajar tinggi dan sedang pada pembelajaran inkuiri. Pada pembelajaran inkuiri siswa dengan 
kemandirian belajar tinggi dan sedang mempunyai prestasi yang sama.

2) $F_{o b s} \in D K$ sehingga $H_{0}$ ditolak artinya ada perbedaan prestasi belajar antara siswa dengan kemandirian belajar tinggi dan rendah pada pembelajaran inkuiri. Apabila dilihat dari rerata siswa dengan kemandirian belajar tinggi adalah 69,2501 dan rerata siswa dengan kemandirian belajar rendah adalah 47,5758. Pada pembelajaran inkuiri siswa dengan kemandirian belajar tinggi mempunyai prestasi yang lebih baik daripada siswa dengan kemandirian belajar yang rendah.

3) $F_{o b s} \notin D K$ sehingga $H_{0}$ diterima artinya tidak ada perbedaan prestasi belajar antara siswa dengan kemandirian belajar sedang dan rendah pada pembelajaran inkuiri. Pada pembelajaran inkuiri siswa dengan kemandirian belajar sedang dan rendah mempunyai prestasi yang sama.

4) $F_{\text {obs }} \notin D K$ sehingga $H_{0}$ diterima artinya tidak ada perbedaan prestasi belajar antara siswa dengan kemandirian belajar tinggi dan sedang pada pembelajaran PBM. Pada pembelajaran PBM siswa dengan kemandirian belajar tinggi dan sedang mempunyai prestasi yang sama.

5) $\quad F_{o b s} \notin D K$ sehingga $H_{0}$ diterima artinya tidak ada perbedaan prestasi belajar antara siswa dengan kemandirian belajar tinggi dan rendah pada pembelajaran PBM. Pada pembelajaran PBM siswa dengan kemandirian belajar tinggi dan rendah mempunyai prestasi yang sama.

6) $F_{\text {obs }} \notin D K$ sehingga $H_{0}$ diterima artinya tidak ada perbedaan prestasi belajar antara siswa dengan kemandirian belajar sedang dan rendah pada pembelajaran PBM. Pada pembelajaran PBM siswa dengan kemandirian belajar sedang dan rendah mempunyai prestasi yang sama.

7) $\quad F_{o b s} \notin D K$ sehingga $H_{0}$ diterima artinya tidak ada perbedaan prestasi belajar antara siswa dengan kemandirian belajar tinggi dan sedang pada pembelajaran konvensional. Pada pembelajaran konvensional siswa dengan kemandirian belajar tinggi dan sedang mempunyai prestasi sama.

8) $\quad F_{o b s} \notin D K$ sehingga $H_{0}$ diterima artinya tidak ada perbedaan prestasi belajar antara siswa dengan kemandirian belajar tinggi dan rendah pada pembelajaran konvensional. Pada pembelajaran konvensional siswa dengan kemandirian belajar tinggi dan rendah mempunyai prestasi sama.

9) $\quad F_{o b s} \notin D K$ sehingga $H_{0}$ diterima artinya tidak ada perbedaan prestasi belajar siswa dengan kemandirian belajar sedang dan rendah pada pembelajaran konvensional. Pada pembelajaran konvensional.

10) 1 siswa dengan kemandirian belajar sedang dan rendah mempunyai prestasi sama. 
Tabel 9 Hasil uji komparasi ganda antar sel pada kolom yang sama

\begin{tabular}{|c|c|c|cl|}
\hline$H_{0}$ & $F_{\text {obs }}$ & $F_{\text {tabel }}$ & \multicolumn{2}{|c|}{ Keputusan } \\
\hline$\mu_{11}=\mu_{21}$ & 22,1728 & 15,7743 & $H_{0}$ & Ditolak \\
\hline$\mu_{11}=\mu_{31}$ & 25,2895 & 15,7743 & $H_{0}$ & Ditolak \\
\hline$\mu_{21}=\mu_{31}$ & 0,3469 & 15,7743 & $H_{0}$ & Diterima \\
\hline$\mu_{12}=\mu_{22}$ & 1,2573 & 15,7743 & $H_{0}$ & Diterima \\
\hline$\mu_{12}=\mu_{32}$ & 7,8714 & 15,7743 & $H_{0}$ & Diterima \\
\hline$\mu_{22}=\mu_{32}$ & 3,6407 & 15,7743 & $H_{0}$ & Diterima \\
\hline$\mu_{13}=\mu_{23}$ & 0,2933 & 15,7743 & $H_{0}$ & Diterima \\
\hline$\mu_{13}=\mu_{33}$ & 0,8683 & 15,7743 & $H_{0}$ & Diterima \\
\hline$\mu_{23}=\mu_{33}$ & 2,3954 & 15,7743 & $H_{0}$ & Diterima \\
\hline
\end{tabular}

Berdasarkan tabel di atas dapat disimpulkan sebagai berikut:

1) $F_{o b s} \in D K$ sehingga $H_{0}$ ditolak artinya ada perbedaan prestasi belajar antara siswa dengan kemandirian belajar tinggi pada pembelajaran inkuiri dan PBM. Apabila dilihat dari rerata dengan inkuiri adalah 69,2501 dan rerata dengan PBM adalah 50,0000. Siswa yang mempunyai kemandirian belajar tinggi pada pembelajaran Inkuiri mempunyai prestasi lebih baik daripada pembelajaran PBM.

2) $F_{o b s} \in D K$ sehingga $H_{0}$ ditolak artinya ada perbedaan prestasi belajar antara siswa dengan kemandirian belajar tinggi pada pembelajaran inkuiri dan konvensional. Apabila dilihat dari rerata dengan inkuiri adalah 69,2501 dan rerata dengan konvensional adalah 47,1667. Siswa yang mempunyai kemandirian belajar tinggi pada pembelajaran inkuiri mempunyai prestasi yang lebih baik daripada pembelajaran konvensional.
3) $F_{o b s} \notin D K$ sehingga $H_{0}$ diterima artinya tidak ada perbedaan prestasi belajar antara siswa dengan kemandirian belajar tinggi pada pembelajaran PBM dan konvensional. Siswa dengan kemandirian belajar tinggi pada pembelajaran PBM dan konvensional mempunyai prestasi sama.

4) $F_{o b s} \notin D K$ sehingga $H_{0}$ diterima artinya tidak ada perbedaan prestasi belajar antara siswa dengan kemandirian belajar sedang pada pembelajaran inkuiri dan PBM. Siswa dengan kemandirian belajar tinggi pada pembelajaran inkuiri dan PBM mempunyai prestasi yang sama.

5) $F_{\text {obs }} \notin D K$ sehingga $H_{0}$ diterima artinya tidak ada perbedaan prestasi belajar antara siswa dengan kemandirian belajar sedang pada pembelajaran inkuiri dan konvensional. Siswa dengan kemandirian belajar tinggi pada pembelajaran inkuiri dan konvensional mempunyai prestasi sama.

6) $F_{o b s} \notin D K$ sehingga $H_{0}$ diterima artinya tidak ada perbedaan prestasi belajar antara siswa dengan kemandirian belajar sedang pada 
pembelajaran PBM dan konvensional. Siswa dengan kemandirian belajar tinggi pada pembelajaran PBM dan konvensional mempunyai prestasi sama.

7) $F_{o b s} \notin D K$ sehingga $H_{0}$ diterima artinya tidak ada perbedaan prestasi belajar antara siswa dengan kemandirian belajar rendah pada pembelajaran inkuiri dan PBM. Siswa dengan kemandirian belajar tinggi pada pembelajaran inkuiri dan PBM mempunyai prestasi yang sama.

8) $F_{\text {obs }} \notin D K$ sehingga $H_{0}$ diterima artinya tidak ada perbedaan prestasi belajar antara siswa dengan kemandirian belajar rendah pada pembelajaran inkuiri dan konvensional. Siswa dengan kemandirian belajar tinggi pada pembelajaran inkuiri dan konvensional mempunyai prestasi yang sama.

9) $\quad F_{o b s} \notin D K$ sehingga $H_{0}$ diterima artinya tidak ada perbedaan prestasi belajar antara siswa dengan kemandirian belajar rendah pada pembelajaran PBM dan konvensional. Siswa dengan kemandirian belajar tinggi pada pembelajaran PBM dan konvensional mempunyai prestasi sama.

\section{KESIMPULAN}

Berdasarkan kajian teori, hasil penelitian, adanya analisis serta mengacu pada perumusan masalah dan pembahasan, dapat disimpulkan sebagai berikut.

1. Prestasi belajar matematika siswa pada pembelajaran inkuiri lebih baik daripada prestasi belajar matematika siswa pada pembelajaran berbasis masalah maupun konvensional. Prestasi belajar matematika siswa pada pembelajaran berbasis masalah lebih baik daripada prestasi belajar matematika siswa pada pembelajaran konvensional.

2. Siswa dengan kemandirian belajar tinggi memiliki prestasi belajar matematika lebih baik dibandingkan siswa berkemandirian belajar sedang, siswa dengan kemandirian belajar sedang memiliki prestasi yang sama baiknya dengan siswa berkemandirian belajar rendah, dan siswa dengan kemandirian belajar tinggi memiliki prestasi yang lebih baik dibandingkan siswa dengan kemandirian belajar rendah.

3. Pada model pembelajaran inkuiri, siswa dengan kemandirian belajar tinggi memiliki prestasi belajar matematika sama baiknya dengan siswa berkemandirian belajar sedang, siswa dengan kemandirian belajar tinggi memiliki prestasi yang lebih baik dibandingkan siswa berkemandirian belajar rendah, dan siswa dengan kemandirian belajar sedang memiliki prestasi yang sama baiknya dengan siswa dengan kemandirian belajar rendah. Pada model pembelajaran PBM dan konvensional, ketiga klasifikasi kemandirian belajar siswa memberikan prestasi belajar yang sama baiknya.

4. Pada siswa dengan kemandirian belajar tinggi, model pembelajaran inkuiri menghasilkan prestasi belajar matematika lebih baik dibandingkan model pembelajaran berbasis masalah (PBM), model 
pembelajaran berbasis masalah (PBM) menghasilkan prestasi belajar matematika sama baiknya dengan model pembelajaran konvensional, dan model pembelajaran inkuiri menghasilkan prestasi belajar matematika lebih baik dibandingkan model pembelajaran konvensional. Pada siswa dengan kemandirian belajar sedang dan rendah, ketiga model pembelajaran menghasilkan prestasi belajar matematika yang sama baiknya.

\section{Daftar Pustaka}

Agus Suprijono. 2010. Cooperative Learning Teori dan Aplikasi PAKEM. Yogyakarta: Pustaka Pelajar.

Alip Sutikno. 2004. Pengaruh Model Pembelajaran Berdasarkan Masalah Terhadap Prestasi Belajar Matematika Ditinjau Dari Kemampuan Operasi Aljabar. Tesis: UNS Surakarta.

Arends, Richard I. 2008. Learning To Teach (Belajar Untuk Mengajar) Buku Dua. Yogyakarta: Pustaka Pelajar.

Baharuddin dan Wahyuni. 2008. Teori Belajar.

Jakarta: Rineka Cipta.

Bayazit, Ibrahim. 1996. "The Influence of Teaching on Student Learning: The Notion of Piecewise Function". International Electronic Journal of Mathematics Education. Vol 5 No.3. Diakses pada 13 Mei 2011.

Beacham, Cindy V. and Shambaugh, Neal. 2007. "Advocacy a Problem-Based Learning (PBL) Teaching Strategy”.
International Journal of Teaching and Learning in Higher Education Volume 19 Number 3 Page 315-324, diakses dari http://www.isctl.org/ijtlhc/ pada tanggal 4 Juli 2011.

Budiyono. 2003. Metodologi Penelitian Pendidikan. Surakarta: UNS Press. . 2009. Statistika Untuk Penelitian Edisi $K e-2$. Surakarta: UNS Press.

. 2011. Penilaian Hasil Belajar. Program Pascasarjana: UNS Press.

Depdiknas. 2003. Undang-undang Republik Indonesia nomor 20 tahun 2003 tentang Sistem Pendidikan Nasional. Depediknas: Jakarta.

Fransiskus Gatot Iman Santoso. 2010. Efektifitas Pembelajaran Berbasis Masalah Dan Pembelajaran Kooperatif Bertipe Group Investigation Terhadap Prestasi Belajar Matematika Ditinjau Dari Kecerdasan Majemuk Siswa Kelas VII SMP Negeri Kota Madiun. Tesis: UNS Surakarta

Goos, Merrilyn. 2004. Learning Mathematics in a Classroom Community of Inquiry, Journal of Research of Mathematics Education, Vol. 35, no. 4, pp 258-291.

Gulo. 2002. Strategi Belajar-Mengajar. Jakarta: PT. Gramedia.

Haris Mudjiman, 2002. Belajar Mandiri. Surakarta: Universitas Sebelas Maret Press

Hmelo-Silver, Cindy and Barrows, Howard S. 2006. "Goals and Strategies of a Problem-based Learning Facilitator" 
The Interdisciplinary Journal of Problem-based Learning Volume 1 Number 1 Page 21-39, diakses dari http://docs.lib.purdue.edu/ijpbl/vol1/iss 1/ pada tanggal 19 Juli 2011

Irzan Tahar dan Enceng. Hubungan Kemandirian

Belajar dan Hasil Belajar pada Pendidikan Jarak Jauh. Jurnal Pendidikan Terbuka dan Jarak Jauh. 7 (2). 91-101, diakses dari http://lppm.ut.ac.id/ptji/72sept06/tahar. pdf pada tanggal 23 Juli 2011

Lambas, dkk. 2004. Materi Pelatihan Terintegrasi Mata Pelajaran Matematika,buku 3. Jakarta: Depdiknas. Martinis Yamin dan Bansu I. Ansari. 2008. Taktik Mengembangkan Kemampuan Individual Siswa. Jakarta: Gaung Persada Press

Mulyono Abddurrahman. 2003. Pendidikan Bagi Anak Berkesulitan Belajar. Jakarta: Rineka Cipta.

Paul Suparno. 1997. Filsafat Konstruktivisme

Dalam Pendidikan. Yogyakarta: Kanisius.

Ruseffendi. 1995. Pendidikan Matematika 3. Jakarta: Departemen Pendidikan Dan Kebudayaan: Bagian Proyek Peningkatan Mutu Guru SD Setara DII.

Sofan Amri dan Ahmadi. 2010. Proses Pembelajaran kreatif dan Inovatif dalam kelas. Prestasi Pustaka Jakarta.

Sri Wahyuni. 2009. Eksperimentasi Model Pembelajaran Berdasarkan Masalah
Pada Subpokok Bahasan Sistem Persamaan Linear Dua Variabel Ditinjau Dari Aktivitas Belajar Siswa Kelas X SMK Se-Kabupaten Boyolali Tahun Pelajaran 2008/2009. Tesis: UNS Surakarta

Strobel, Johannes and van Barneveld, Angela. 2009. "When is PBL More Effective? A Meta synthesis of Meta analyses Comparing $\mathrm{PBL}$ to Conventional Classrooms". The Interdisciplinary Journal of Problem-based Learning Volume 3 Number 1 Page 44-58. diakses dari http://docs.lib.purdue.edu/ijpbl/vol3/iss 1/ pada tanggal 19 Januari 2012

Sugiyono. 2007. Statistik Untuk Penelitian. Penerbit Alfabeta Bandung.

Syaiful Bahri Djamarah. 2008. Psikologi Belajar. Edisi 2. Jakarta: Rineka Cipta. dan Aswan Zain. 2002. Strategi Belajar Mengajar. Bandung: Rineka Cipta.

Syaiful Sagala. 2009. Kemampuan Profesional Guru dan Tenaga Kependidikan. Bandung: Alfabeta.

Tarono. 2006. Pengaruh Penggunaan Metode Inkuiri Terbimbing dan Inkuiri Bebas Termodifikasi Terhadap Prestasi Belajar Fisika Ditinjau dari Sikap Ilmiah. Tesis: UNS Surakarta

Tedjo Susanto. 1999. Mengajar Sains Dengan Cara Discovery Inquiry. Yogyakarta: Universitas Negeri Yogyakarta. 
Tim Penyusun Kamus Pusat Pembinaan dan Pengembangan Bahasa. 2001. Kamus Besar Bahasa Indonesia. Jakarta: Balai Pustaka.

Wina Sanjaya. 2010. Strategi Pembelajaran Berorientasi Standar Proses Pendidikan. Jakarta: Kencana

Winch-Dummett, Carlene . 2004. "Teaching Processes and Practices for an Australian Multicultural Classroom: Two Complementary Models". International
Education Journal Vol 4, No 4, 2004. Diakses pada 21 Desember 2011. Winkel, W.S. 1996. Psikologi Pengajaran . Jakarta: Grasindo.

Zulharman. 2009. Model Kemandirian Belajar dan Peran Guru. http://zulharman79.wordpress.com/200 9/12/27/model-tentang-kemandirianbelajar-siswa-dan-peran-guru. Diakses tgl 17 Juni 2011 